O'Malley, M. und Norris, E. (2000): The Mayor's Plan to Dramatically Reduce Crime in Baltimore. Baltimore.

Ouimet, M. (2002): Explaining the American and Canadian crime »drop« in the I990's. In: Canadian Journal of Criminology 44. Jg. S. 33-50.

Parenti, C. (1999): Lockdown America. London und New York

Piven, F. und Cloward, R. (I993): Regulating the Poor. Updated edition. New York [1971].

Rath, M. (2000): Command Decisions. In: Baltimore City Paper, I9. 04. 2000.

Redmond, H. (200I): The War on Drugs. Myth and Reality. In: International Socialist Review H. Is December 2000 - January 200 I, S. 35-42.

Sack, F. (I995): Prävention - ein alter Gedanke in neuem Gewand. In: Gössner, R. (Hrsg.): Mythos Sicherheit. Baden-Baden, S. 429-456

Siegel, F. (1995): Reclaiming our Public Spaces. In: Kasinitz, P. (Hrsg.): Metropolis. New York, S. $369-383$.

Skogan, W. und Hartnett, S. (1997): Community Policing, Chicago Style. New York und Oxford.

Smith, N. (200I): Global Social Cleansing: Postliberal Revanchism And the Export of Zero Tolerance. In: Social Justice 28. Jg. S. 68-74.

Wacquant, L. (2000): Elend hinter Gittern. Koblenz.

Ders. (1997): Vom wohltätigen Staat zum strafenden Staat: Über den politischen Umgang mit dem Elend in Amerika. In: Leviathan 25. Jg. S. 50-66.

Wilber, D. (200I): Reinventing police work. In: Baltimore Sun, I 2. 08. $200 \mathrm{I}$.

Wilson, J. (1996): Foreword. In: Kelling, G., Coles C.: Fixing Broken Windows. New York u. a., S. xiii-xvi.

Ders. und Kelling, G. (1982): Broken Windows. In: Atlantic Monthly H. 3 S. 29-38.

Zimring, F. und Fagan, J. (2000): The Search for Causes in an Era of Crime Declines: Some Lessons From the Study of New York City Homicide. In: Crime \& Delinquency 46. Jg. S. $446-456$.

Zurawik, D. (2002): Commissioner brings credibility to >Wire role. In: Baltimore Sun, 23. 8. 2002 .

\title{
Henry Friedlander Das Novemberprogrom und die Justiz nach 1945
} Eine Fallstudie

This essay deals with a criminal trial, part of my current research into the postwar trials of the Kristallnacht perpetrators. These were not Allied trials, but proceedings in the newly reconstituted German courts. ${ }^{\text {I }}$ There were hundreds of Kristallnacht trials covering every region of Germany and Austria; they commenced in late I945 and petered out in the early i 950 s. For this essay, I have selected a case from the holdings of the Staatsarchiv in Oldenburg, where it is listed as Case No. I I93. ${ }^{2}$

Case I 93 concerned an unusual Kristallnacht story. Actually, not a Kristallnacht story at all, although it is listed as such by the archive. The November pogrom took place on the 9 th and the roth; Case I 93 occurred on the evening of the I 5 th. More important, the November pogrom was directed against Jews; the victims of Case I 193 were not Jewish. It is the only such case I have found, and that makes it rather unusual.

* This is a revised version of my presidential address (Eine Berliner Pflanze-An Unusual Kristallnacht Story), delivered at the annual meeting of the German Studies Association, San Diego, 4 October 2002. It was published in German Studies Review XXVI/I (February 2003), pp. I-I4.

I See Henry Friedlander, "The Judiciary and Nazi Crimes in Postwar Germany, «in: Simon Wiesenthal Center Annual I (1984): 27-44.

2 Staatsarchiv Oldenburg, Bestand I40-5, Nr. I I 93: Verfahren Hartmann, 5 Js I I07/47, 9 Ks 2/50, 2 vols. 
This story has two separate but related strands. At this point it is best to summarize events on I 5 November 1938 , and the days that followed. But first, the location and the victims. Events took place in the town of Sande in the state of Oldenburg. The city of Oldenburg was the capital of the state; the places that play a role in this story were located in the Landkreis of Friesland, about 30-35 miles northeast of Oldenburg. The capital of the Friesland district was Jever, seat of the Landrat; it had a population of almost 7.000 in 1939. Sande was located in what we would today call the suburbs of Wilhelmshaven, whose harbor served as home for the German navy. The population of Sande was 2.602 in 1933 , and $4.8 \mathrm{I}_{3}$ in 1939 ; the postwar court counted about 3.000 inhabitants for November 1938.3 It was a really small town; witnesses called it a village, that is, a Dorf.

The victims were Ulrich and Mia Cornelßen, a husband and wife (Ehepaar), both not Jewish. Ulrich ran a business in Sande selling Düngemittel und Torfstreu; after the war his business, then located in Wilhelmshaven, expanded to deal in Baustoffe und Futtermittel, as well as Düngemittel und Torfstreu. They lived on a property they owned in Sande-Neufeld; they had lived there a long time. The Cornelßens occupied the ground floor and rented out two floors above them. Ulrich and Mia had married in I927; they had no children (»kinderlos verheiratet «). ${ }^{4}$

Let us now consider the first strand of our story. By about 8:00 PM on the evening of November i 5 th, a crowd of people had assembled in front of the Cornelßen property and started throwing stones at the windows of the Cornelßen apartment, breaking all of them. At the same time several men forced open the door of the apartment, and soon thereafter men and boys filled the apartment and started to demolish its furniture. ${ }^{5}$

We might want to enquire about the size and composition of this crowd. Witnesses later testified that it was a »mehrhundertköpfige Menschenmenge «. ${ }^{6}$ A large proportion of the crowd were members of the SA, the brownshirt storm troopers of the Nazi movement; there were also a substantial number of teenage boys, all members of the Hitler Youth (HJ). They did not, however, wear their uniforms. ${ }^{7}$ But we also know that the crowd included many others, specially women and children, who had come to look and stayed to participate. It was a cross section of the Sande population; one witness later testified »daß sich damals nahezu das ganze Dorf bei Cornelßen traf $\ll .8$ Of course, they did not all throw stones, but they made their sympathies very clear. As witnesses would later report, »In der johlenden Menge fielen Ausdrücke wie >Judenfreund und Judenschwein. « 9

Obviously, we must ask, how did all this come to pass? Why did all those people assemble there that evening? The postwar investigation concluded that the attack on the Cornelßens was not spontaneous, but had been planned in advance by the local Nazi party. ${ }^{\circ}$ Local opinion as well as the postwar court pointed to Hermann Hartmann as the ringleader in this affair. ${ }^{\text {II }}$ Hartmann, a local school teacher, was a Sturmführer who headed the Sande SA; he was also the senior post commander

3 Ibid., vol. 2, pp. I 34-69: Landgericht (LG) Oldenburg, Urteil gg. Hermann Hartmann u. a., 9 Ks 2/50, Is Feb. 1950 (reference on p. I4I).

4 Ibid., vol. I, p. I 8: Ulrich Cornelßen to Oberstaatsanwalt (OStA) Oldenburg, 22 Aug. 1946; vol. 2, pp. I3469: LG Oldenburg, Urteil Hartmann, $9 \mathrm{Ks} \mathrm{2/50,} \mathrm{Is} \mathrm{Feb.} \mathrm{I950} \mathrm{(reference} \mathrm{on} \mathrm{p.} \mathrm{I4I).}$

5 Ibid., vol. 2, p. I 34-69: LG Oldenburg, Urteil Hartmann, 9 Ks 2/50, Is Feb. I950 (reference on pp. I42-44).

6 Ibid., vol. I, pp. 44-48: interrogation of Karl Gösseljohanns, Oldenburg, I 2 Dec. 1946.

7 Ibid., vol. I, pp. I35-36: interrogation of Ernst Hahn, Sande, I9 Oct. 1948; vol.2, pp. I34-69: LG Oldenburg, Urteil Hartmann, 9 Ks 2/50, Is Feb. I950 (reference on p. I42).

8 Ibid., vol. I, p. I06: Amtsgericht Wilhelmshaven, interrogation of Antje Peters, verwitwete Metzdorf, geb. Kampen, 23 Mar. I948.

9 Ibid., vol. I, pp. 44-48: interrogation of Karl Gösseljohanns, Oldenburg, I 2 Dec. I946.

Io Ibid., vol. 2, pp. I 34-69: LG Oldenburg, Urteil Hartmann, 9 Ks 2/50, I 5 Feb. I950 (reference on p. I 53 ).

I I Ibid., vol. I, pp. 55: Polizei-Ermittlungsbericht, Sande, 29 Dec. I946. 
(Standortältester) of the party formations in Sande. ${ }^{12}$ He had called a special meeting of SA and HJ, and had ordered that they assemble near the Cornelßens' property in civilian clothes. The Hitler Youth were in addition ordered to collect and bring stones. ${ }^{13}$

Eventually, the destruction of the apartment was complete, and Hartmann told the men and especially the boys in the apartment to leave: »So jetzt ist es gut, jetzt geht nach Hause. ¿ $^{14}$ Thereafter, Hartmann called the police. As the postwar court stated, calling the police after the operation had ended, »entsprach den gerichtsbekannten Methoden, die damals bei allen derartigen Aktionen von den Partei- und SA-Dienststellen zum Zwecke der Tarnung angewendet wurden. «15 With the arrival of the police we can turn to the second strand of our story.

Not many police officers were stationed in Sande. Only two are ever mentioned in this case, and both arrived at the scene after the destruction of the Cornelßen property had been completed. Karl Gösseljohanns, a non-commissioned officer of the Gendarmerie, was the senior officer in Sande with the title of Gendarmeriekommissar. He was accompanied by Oberwachtmeister Frost, his subordinate, who was killed in the war and thus played no part in the postwar case. Gösseljohanns urged the members of the crowd to go home, but made no further efforts to disperse them. After viewing the destruction, he selected several men to stand guard to prevent looting. He picked men suggested by Hartmann; every one was a member of the SA. ${ }^{16}$

The Cornelßens were not at home during the attack upon their property, something the crowd had first discovered when they broke into the garage and found their car missing. ${ }^{17}$ They were visiting friends and were expected to return that night. The remaining crowd was waiting for the return of the Cornelßens; many among those waiting commented »dann wollten sie Cornelßen mit seinem Kraftwagen in den Graben stossen. ${ }^{18}$ All cars that passed were stopped by members of the crowd to check whether they contained the Cornelßens. ${ }^{19}$ Gösseljohanns did not intervene. Finally, at about I:०० AM, already November I6th, there were shouts that they are coming. Let us follow the account later provided by the Cornelßens to describe the events that followed. ${ }^{20}$

Gösseljohanns stopped their car and told them that he had to take them to Jever, because the Landrat urgently wanted to see them. Gösseljohanns first spent some time talking to a group of SA men lined up near the car, then made the Cornelßens drive to a nearby gas station. There they had to leave their car and were placed into another car, one Gösseljohanns had rented along with a driver. When Mia Cornelßen asked him whether they were under arrest, Gösseljohanns replied »noch nicht, $«^{21}$ repeating that

I 2 On Hartmann, see ibid., vol. I, pp, 77-79, I 59 : interrogation of Hermann Johann Hartmann, I 5 Apr. I947, 27 Feb. 1949.

I 3 Ibid., vol. 2, pp. I 34-69: LG Oldenburg, Urteil Hartmann, 9 Ks 2/50, Is Feb. I950 (reference on p. I 42).

I4 Ibid., vol. I, pp. 39-40: interrogation of Antje Peters, verwitwete Metzdorf, geb. Kampen, Wilhelmshaven, 25 Nov. 1946.

Is Ibid., vol. 2, pp. I34-69: LG Oldenburg, Urteil Hartmann, 9 Ks 2/50, Is Feb. I950 (reference on p. I 55 ).

I6 Ibid., vol. I, pp. 77-79: interrogation of Hermann Johann Hartmann, Is Apr. 947.

I7 Ibid., vol. I, pp. 66-67: interrogation of Martin Köster, Sande, 20 Mar. I947.

I 8 Ibid., vol. I, p. 5o: interrogation of Alwin Gode, Sande i7 Dec. I946.

I9 Ibid., vol. I, pp. 39-40: interrogation of Antje Peters, verwitwete Metzdorf, geb. Kampen, Wilhelmshaven, 25 Nov. 1946.

20 Ibid., vol. I, pp. I 2-I4: OStA Bormann, Oldenburg, testimony of Ulrich Cornelßen, I7 Aug. I946; vol. I, pp. 36-37: testimony (under oath) of Mia Cornelßen, geb. Krumnow, Wilhelmshaven, 22 Nov. I946; vol. I, p. 38: statement of Ulrich Cornelßen, Wilhelmshaven, 22 Nov. 1946; vol. I, p. 94: Amtsgericht Wilhelmshaven, testimony of Ulrich and Mia Cornelßen, 3 Sept. 1947; vol. I, pp. I 27-29: Ulrich Cornelßen, Wilhelmshaven, to Staatsanwaltschaft (StA) Oldenburg, 20 July I948; vol. I, pp. I 30-3 I: Mia Cornelßen, Wilhelmshaven, to StA Oldenburg, 20 July 1948.

2 I Ibid., vol. I, p. 8: Ulrich Cornelßen to Georg Joel, Ministerpräsident and Innenminister of Land Oldenburg, [1938]. 
the Landrat wanted to see them. The Cornelßens were placed in the back of the car;

Frost sat down between husband and wife, and Mia later remembered »nun wusste ich schlagartig, was los war. $\ll^{22}$

I might add that members of the crowd, who had earlier supposedly planned to do harm to the Cornelßens, voiced their approval of Gösseljohanns' actions after the departure of the Cornelßens with statements like »Na, die sind in >Nummer Sicher,« und »die kommen nicht wieder. $\ll^{23}$

Upon arrival in Jever, the car stopped in front of the local jail. Gösseljohanns no longer mentioned the supposed meeting with the Landrat, but told them about the destruction of their apartment, which meant that they could not stay at home. When Cornelßen suggested that they book rooms at a Jever hotel at his expense, Gösseljohanns refused this request, instead turning them over to Justizwachmeister Dietrich Wille, who was in charge of the prison. Gösseljohanns now told the Cornelßens that they were under political arrest.

In the car on the way to Jever, Mia Cornelßen had already complained to her husband about severe pain in her back. Both husband and wife asked Gösseljohanns at the jail to call a physician. Gösseljohanns refused, indicating that political arrest does not permit calling a physician. They later repeated this request to Wille, who repeated Gösseljohanns' exact words: »In politischer Haft gibts keinen Arzt. $\ll^{24}$ Mia was, however, able to obtain a large package of cotton from Wille. The Cornelßens were then placed, on Gösseljohanns' orders, into separate cells on different floors.

Let us interrupt the narrative to point out that after the war both Gösseljohanns and Wille denied that the Cornelßens had ever asked for a physician. At first Gösseljohanns also denied that they had ever asked for a hotel room, but later admitted that they had done so. ${ }^{25}$

Mia Cornelßen was pregnant (2, 3, and 4 months are mentioned), and during the night she suffered a miscarriage in her cell. She called for Wille and again asked for a physician, because she feared heavy bleeding. Wille refused. Next morning her husband was permitted into her cell for a shared meal. Mia used water and her own handkerchiefs to clean the blood from the floor. There was no blood on the bed, since both she and her husband had slept fully clothed, because they did not want the filthy linens the prison provided to touch their skin. Her husband emptied the toilet pail containing the fetus, the bloody cotton, and the bloody handkerchiefs. Mia Cornelßen obviously knew what she was doing, since she apparently had already had previous miscarriages.

The Cornelßens remained in jail for 38 hours. By that time Gösseljohanns had finally filed his report, and thereupon the deputy Landrat, Dr. Drückhammer, released them.

Gösseljohanns' report, dated I6 November I938, was available to the postwar investigators. ${ }^{26}$ Gösseljohanns did not send it to his superior in the Gendarmerie in Jever, who was legally the one who should have decided on the arrest of the

22 Ibid., vol. I, pp. 36-37: testimony (under oath) of Mia Cornelßen, geb. Krumnow, Wilhelmshaven, 22 Nov. I 946.

23 Ibid., vol. I, pp. 39-40: interrogation of Antje Peters, verwitwete Metzdorf, geb. Kampen, Wilhelmshaven, 25 Nov. 1946.

24 Ibid., vol. I, p. 8: Ulrich Cornelßen to Georg Joel, Ministerpräsident and Innenminister of Land Oldenburg, [1938].

25 Ibid., vol. I, pp. 44-48: interrogation of Karl Gösseljohanns, Oldenburg, I 2 Dec. 1946.

26 Ibid., vol. I, p. 6: Gendarmeriemeister Gösseljohanns, Gendarmeriestation Sande, Amt Friesland, Land Oldenburg, Bericht über einen Menschenauflauf und Demolierung der Behausung des Kaufmanns Ulrich Cornelßen ... betr. Landesfriedensbruch, I6 Nov. 1938. 
Cornelßens, but only provided him a brief oral account. ${ }^{27} \mathrm{He}$ sent his report to the Landrat in Jever and to the state's attorney in Oldenburg. After the war he was accused of having written a report to the Gestapo, something he vigorously denied. Confronted, however, by evidence from his own report, he admitted that his report did indeed reach the Gestapo, but emphasizing »dass ich an die Gestapo keinen Sonderbericht erstattet habe, sondern dieser Behörde nur eine Abschrift zugehen ließ. Hierzu war ich verpflichtet, da es sich um eine Sache mit politischen Einschlag handelte. $\ll^{28}$

Concerning the perpetrators of the attack on the Cornelßens' property, Gösseljohanns concluded in his report that so far he had not found any evidence that might lead to the discovery of those who instigated or carried it out. Still, he had been busy. During the night he had already, or so he reported, discovered a great deal about the Cornelßens: (I) even before the so-called seizure of power, in Holland Cornelßen founded a newspaper financed by a Jew; (2) shortly thereafter he declared that if war comes, he would be the first to cross the border; (3) in the last plebisite, Cornelßen did not vote, although he had obtained a ballot; and (4) »Trotzdem allen bekannt ist, dass man nicht mit Juden handeln soll, hat Cornelßen dem Juden de Taube, Horster Grashaus, am 30. 6. d.Jrs. einen Waggon Torf und einen Waggon Torfstreu geliefert. «Gösseljohanns concluded »Da in der Wohnung selbst dann noch Marxistische Schriften u. a. - Sowjet Paradies und Freimauererschriften vorgefunden wurden und somit sich der Verdacht der staatsfeindlichen Einstellung stärkte, wurde die Geheime Staatspolizei sofort von dem Geschehenen und Wahrnehmung in Kenntnis gesetzt «.

It should be noted that the Gestapo did indeed search (durchwühlte) the Cornelßens' apartment and confiscated a number of books. ${ }^{29}$ But there is no evidence that the Gestapo interfered with the Cornelßens thereafter.

In his report Gösseljohanns did not mention »political arrest, « but instead remarked that he placed the Cornelßens under »protective custody « for their own protection, because there was danger that the excited population would attack them. But Gösseljohanns must have known that Schutzhaft was the term used in those days to camouflage the fact of a »political arrest. «Concerning Gösseljohanns, a postwar report observed that the citizens of Sande saw in him a »verständiger und guter Gendarm. "The report added that »er hat allerdings mit den Kreisen der Partei und der sonstigen Führerschaft viel verkehrt. «30

After their release, the Cornelßens did not simply accept what happened, but moved to do something about it. Mia Cornelßen, the driving force in the couple's attempt to get justice, collected sufficient information from inhabitants of Sande to form a relatively clear picture of what had occurred on their property. At the same time, she attempted to get a medical examination and also a certificate proving that she had undergone a miscarriage. She first went to a Dr. Anton Jacoby at Willehad hospital in Wilhelmshaven. He refused because he did not wish to get involved with the SA. She next went to see the Amtsarzt Dr. Fritz Hildebrandt, director of the Jever health department, but he also refused, unless she could provide a court order.

The Cornelßens finally had an audience with Georg Joel, prime minister and interior minister of Oldenburg. Ulrich Cornelßen had already filed a complaint with his office,

27 Ibid., vol. I, pp. 4I-42: Kripo Wilhelmshaven to StA Oldenburg, 30 Nov. I 946, »Abschließender Ermittlungsbericht. « Gösseljohanns’ superior was Oberleutnant der Gend. Paul Lindner, Kreisführer in Jever.

28 Ibid., vol. I, pp. 44-48: interrogation of Karl Gösseljohanns, Oldenburg, I 2 Dec. I 946.

29 Ibid., vol. I, p. 7, 9: Bericht über den Überfall auf die Wohnung Ulrich Cornelßen, n. d. [postwar]. Internal evidence indicates Cornelßen as author.

30 Ibid., vol. I, pp. 41-42: Kripo Wilhelmshaven to StA Oldenburg, 30 Nov. 1946, »Abschließender Ermittlungsbericht.« 
describing the events of both the attack and the incarceration, including the miscarriage. Joel referred them to Polizeirat Ahrens, who told them that there was no physician available, although the entrance to the police surgeon's office was just next door. In his postwar testimony, Ahrens agreed that Mia Cornelßen asked to see a physician, and that he could have provided one, but had seen no reason to do so, because he had not found her trustworthy. Cornelßen's complaint was later rejected, citing Gösseljohanns' report and the testimony of the prison warden Wille. ${ }^{31}$

The Cornelßens also filed a complaint with the Staatsanwaltschaft in Oldenburg. But the Gestapo kept all records of this case for almost a year, so that the state's attorney could not act. By the time the records were returned, the amnesty of September 1939 made the matter moot. ${ }^{32}$ Meanwhile Cornelßen was attacked in the Stürmer and in the Schwarzes Korps. Shortly thereafter, the Cornelßens took their lawyer's advice and left Sande for Mecklenburg. ${ }^{33}$

We must now ask why their neighbors attacked the Cornelßens? There is no question that the local Nazi party disliked them intensely. The postwar indictment concluded that the party agitated against the Cornelßens by »Verbreitung von unkontrollierbaren Gerüchten« as well as through a »planmäßig geführte Hetze.«34 As we have seen, these party rumors were reflected in the accusations leveled by Gösseljohanns in his report. But in some ways the party only reflected general attitudes; the Cornelßens were simply not popular in Sande. The postwar court found that the Cornelßens »hatten mit der Bevölkerung von Sande nicht den in einem solchen Dorfe üblichen Kontakt; sie lebten verhältnismäßig abgeschlossen für sich.«3s This viewpoint was reflected in most witness testimonies.

Even individuals well disposed towards the Cornelßens admitted the existence of this popular dislike. The Sande businessman Johann Smit described the Cornelßens as »strebsame und fleissige Menschen«, but added that »man konnte aber immer wieder feststellen, daß die Eheleute Cornelßen bei fast allen Einwohnern von Sande nicht sehr beliebt waren. ${ }^{3^{6}}$ Antje Peters, their upstairs neighbor whose daughter liked Mia Cornelßen very much, testified in the same way. As a longtime school administrator (hatte Verwaltung der Schule) she knew almost everyone in Sande, and commented that "Cornelßen hatte in Sande sehr viele Feinde. Zum Teil war es wohl Neid, denn dem Kaufmann Cornelßen ging es sehr gut. «37

There were of course political reasons for the party's dislike. Ulrich Cornelßen had prior to 1933 been a member of the Reich Banner and of the Iron Front. But he had not been active since 1933, and the failure of the Gestapo to act against him indicates that no real evidence existed against him. Still, amongst the populace of Sande the Cornelßens were considered communists as well as people who maintained social and business contacts with Jews. ${ }^{3}$

3 I Ibid., vol. I, pp. I 27-29: Ulrich Cornelßen, Wilhelmshaven, to StA Oldenburg, 20 July I948; vol. I, p. 94 : Amtsgericht Wilhelmshaven, Testimony Ulrich and Mia Cornelßen, 3 Sept. I947; vol. I, p. 8: Ulrich Cornelßen to Georg Joel, Ministerpräsident and Innenminister of Land Oldenburg, [1938]; vol. I, pp. I9I206: StA Oldenburg, Anklageschrift gg. Hermann Hartmann u. a., 5 Js I I 07/47, I 3 Apr. 1949 (reference on p. 205); vol. I, pp. 98-99: Memo from Ahrens, Oldenburg, I7 Sept. [1947].

32 Ibid., vol. I, pp. I9I-206: StA Oldenburg, Anklage Hartmann, s Js I I07/47, I 3 Apr. I949 (reference on p. 205).

33 Ibid., vol. I, pp. I 2-I4: OStA Bormann, Oldenburg, testimony of Ulrich Cornelßen, I7 Aug. I946.

34 Ibid., vol. I, pp. I9I-206: StA Oldenburg, Anklage Hartmann, s Js I I07/47, I 3 Apr. I 949 (reference on p. 199).

35 Ibid., vol. 2, pp. I 34-69: LG Oldenburg, Urteil Hartmann, 9 Ks 2/50, Is Feb. I950 (reference on p. I4I).

36 Ibid., vol. I, p.54: interrogation of Kaufmann Johann Smit, Sande, 28 Dec. 1946.

37 Ibid., vol. I, pp. 39-40: Amtsgericht Wilhelmshaven, interrogation of Antje Peters, verwitwete Metzdorf, geb. Kampen, 25 Nov. 1946.

38 Ibid., vol. I, p. I I : Kripo Wilhelmshaven to StA Oldenburg, 2 Oct. 1947. 
Popular hostility was, however, directed more against Mia Cornelßen than against her husband. Every single witness statement stressed this fact. It appeared to be based on her status as an outsider from Berlin, a city not exactly popular in villages such as Sande. Ironically, she was not actually a native of Berlin. She was born in Ketzin near Potsdam, and Ketzin was a village probably even smaller than Sande. Most witnesses pointed to Mia Cornelßen's conflict with the teenage boys of the village. The evidence presented was anecdotal and concerned a certain song, popular at the time, that the Hitler Youth (and often also the SA) whistled or sang every time they marched past the Cornelßens' house. The title of the song was »Du Berliner Pflanze, « and Mia obviously considered this song extremely insulting. ${ }^{39}$

The following is the complete text: ${ }^{4}$

Denkste denn, denkste denn,

Du Berliner Pflanze,

Denkste denn ick liebe dir,

Wenn ick mit dir tanze?

Ach du verrücktes Aas,

Ick lieb dir nur zum Spass,

Denkste denn ick liebe dir,

Wenn ick mit dir tanze?

In English it reads as follows: ${ }^{41}$

Didja think, didja think,

You floozy of Berlin,

Didja think I'd really love you,

When our dance was done?

Oh you crazy rascal,

I loved you just for fun,

Didja think I'd really love you,

When our dance was done?

Mia Cornelßen complained several times to the police, that is, to Gösseljohanns, who passed it on to the SA and the $\mathrm{HJ}$ with the expected result that nothing changed. ${ }^{42}$ Nothing happened in the case until I946, by which time the Cornelßens had returned to the region, but not to Sande, reopening their business in Wilhelmshaven. The state of Oldenburg was in the British zone of occupied Germany; in November 1946 the state of Oldenburg was merged into the newly created state of Lower Saxony.

On I June 1946, the attorney general in Oldenburg sent a memo to the state's attorney, ordering him to open an investigation against Gösseljohanns on the basis of $\ 34 \mathrm{I}$ StGB: Freiheitsberaubung im Amte. He also requested that he inform the chief of the Oldenburg police. As a result Gösseljohanns was suspended from service on 10 September 1946.43

At first the state's attorney told Cornelßen that there was no legal basis for his case, but he did proceed after Cornelßen produced evidence that the Gerichtsoffizier der

39 Ibid., vol. I, pp. 44-48: interrogation of Karl Gösseljohanns, Oldenburg, I 2 Dec. I946; Ibid., vol. I, I 37-38: interrogation of Johann Dirnberger, Sande, I9 Aug. I948; vol. 2, pp. I34-69: LG Oldenburg, Urteil Hartmann, $9 \mathrm{Ks}$ 2/50, Is Feb. I950 (reference on p. I4I).

40 Text of the two stanzas kindly provided by Professor Gerhard Weiss, Department of German, University of Minnesota.

4I Translation by Professor Benjamin Friedlander, Department of English, University of Maine.

42 Ibid., vol. I, pp. 44-48: interrogation of Karl Gösseljohanns, Oldenburg, I 2 Dec. 1946.

43 Ibid., vol. I, p. I: GStA Oldenburg to StA Oldenburg, I June 1946. 
Militärregierung believed that it was actionable.44 The case would then proceed slowly - through the German justice system; it did not end until late March I952. The investigation of Gösseljohanns did not, however, lead to an indictment, and on I May 1947 he returned to police duty.45 The postwar police and state's attorney could not discover any evidence to contradict Gösseljohanns' contention that he acted correctly and within the law: that he arrived late, was surprised by what had happened, and took the Cornelßens to jail for their own protection. The Cornelßens saw it differently. They argued that he had prior information, made sure not to arrive until Hartmann called him after the damage had been done, and then arrested the victims and not the perpetrators.

The two parties thus presented two different interpretations. Since there was no hard evidence and witnesses would not talk, the state's attorney did not indict. But the Cornelßens' conclusions were most reasonable. On the night of the i 5 th, a vast crowd of onlookers assembled to watch the attack on the Cornelßens' property; as Antje Peters testified, »dass sich damals fast das ganze Dorf bei Cornelßen traf. «46 Is it in fact reasonable to assume that Gösseljohanns, on good terms with the town and its party leaders, was the only one left in the dark? Or is it more reasonable to assume that he was part of a conspiracy, which provided for the removal of the Cornelßens from Sande.

Even after Gösseljohanns had filed his report, he visited the Cornelßens several times to interrogate them about their relations with Jews, and also attempted to intimidate them about pursuing their own investigation. He talked to the witnesses mentioned by the Cornelßens, but dropped his inquiry if a witness backed the victims. ${ }^{47}$ At the same time he was never able to find a single perpetrator.

Knowing the way the wind was blowing after the war, Gösseljohanns added an unsolicited statement at the end of his postwar interrogations: »Ich betone abschliessend, daß ich mich auch Juden gegenüber nie zu irgendwelchen Übergriffen habe hergeben lassen. « To prove this point he offered the name of a witness, whom he described as follows: »Dieser Zeuge ist $\mathrm{m}$. W. im Sinne der Nazigesetzgebung Mischling ersten oder zweiten Grades gewesen . $^{8}$

The failure to move against Gösseljohanns is not surprising; in postwar Germany police officers rarely had to answer for their pre-1945 crimes. For example, in the trials of the so-called informers, the civilians who informed against their neighbors went to jail, while virtually none of the police who arrested the victims as well as the judges who sentenced them were ever convicted. 49

Dietrich Wille, the prison warden, was not quite as lucky as Gösseljohanns. The state's attorney included him in the indictment against the SA members placed on trial for the attack against the Cornelßens' property. Unlike the storm troopers, Wille was accused of a crime falling under $\mathbb{S} 340$ StGB: Körperverletzung im Amte.

Although Gösseljohanns had set the stage for the treatment of the Cornelßens when he refused to call a physician and ordered husband and wife to be placed in separate cells on different floors, Wille was responsible for their welfare after Gösseljohanns had left Jever. As Mia Cornelßen's condition deteriorated during the night, Wille remained

44 Ibid., vol. I, p. I 8: Ulrich Cornelßen to OStA Oldenburg, 22 Aug. 1946.

45 Ibid., vol. 2, p. 26r: Polizeimeister Gösseljohanns, Polizeiposten Hude, to OStA Oldenburg, Io Oct. I952; vol. 2, p. 27 I: Polizeimeister i. R. Gösseljohanns, Hude i. O., to GStA Oldenburg, 7 Apr. I953.

46 See above, note 8.

47 Ibid., vol. I, pp. I 2-I4: OStA Bormann, Oldenburg, testimony of Ulrich Cornelßen, I7 Aug. I946.

48 Ibid., vol. I, pp. 44-48: interrogation of Karl Gösseljohanns, Oldenburg, I 2 Dec. I 946.

49 See the cases of the category Denunziantenverbrechen, in: Justiz und NS-Verbrechen: Sammlung deutscher Strafurteile wegen nationalsozialistischer Tötungsverbrechen, ed. Adelheid L. Rüter-Ehlermann and C. F. Rüter, 25 vols. so far (Amsterdam: University Press Amsterdam, I968 -). 
adamant about providing no medical aid for political prisoners; he would argue after the war that upon their arrival in jail all such prisoners immediately demanded to see a physician. When Mia Cornelßen continued to complain about »fürchterliche Schmerzen, « he only replied that »die Jüdinnen vor einigen Tagen seien auch sämtlichst zusammengebrochen « ${ }^{\circ}-$ I guess we could consider him an equal opportunity sadist.

After the war, Wille simply denied everything. He claimed he was never asked to call a physician, in his opinion Mia Cornelßen was healthy while in his custody, and he knew nothing about a miscarriage. But the indictment cited testimony Wille had given in I938, in which he admitted that Mia Cornelßen »ihm gesagt habe, dass sie im zweiten Monat schwanger sei und daß es wohl wieder eine Fehlgeburt geben könne. "s'Wille's wife supported his story. She testified that she found no blood on the linen, adding »mir ist auch nicht aufgefallen, dass ihre Bettwäsche dreckiger war als bei anderen Inhaftierten. «s2 Although she had never even seen Mia Cornelßen, she concluded that there had been no miscarriage.

The state's attorney argued in his indictment that the Cornelßens were speaking the truth. He pointed out that in their 1938 complaint the Cornelßens had basically already provided the same details as they were doing after the war. The state's attorney summarized that »Unter Berücksichtigung der damaligen politischen Verhältnisse ist es aber ganz ausgeschlossen anzusehen, dass sie dies getan hätten, wenn ihre Angaben nicht auf Wahrheit beruhten, « and then concluded that »Demgegenüber erscheint die Aussage der Zeugin Wille, der Ehefrau des Angeschuldigten, dass die Zeugin Cornelßen im Gefängnis keine Fehlgeburt gehabt habe, nicht glaubhaft «.53

The court, however, did not agree. It found in its decision of February I950 that there had been no miscarriage. It considered the testimony of the Cornelßens questionable, because they had an interest in the outcome of the trial. This was certainly a strange argument, since the defendant certainly had an even greater interest in his own fate. It also leaned heavily on the testimony of the expert witness, Dr. Jacobs, who found that Mia Cornelßen was »hochgradig nervös «, and leans toward exaggeration. He found that there could not have been a miscarriage. Furthermore, Dr. Jacobs argued that in any case bodily injury could not have applied, because the miscarriage would not have been avoided by the presence of a physician, and there was no need for medical aid since the miscarriage had no complications. In contrast to its view of Mia Cornelßen, the court found Wille to be a »zuverlässiger und pflichtbewusster Beamter, « and thus believed his statement that Mia Cornelßen was healthy during her stay in his jail.s4

One caveat before we condemn the judges. This German Schwurgericht included in I 950 three judges and six jurors (all men). But theirs was not our classical jury system. On the question of guilt or innocence, and also on the sentence, the jurors could outvote the judges. In that case the judges would have had no choice but to write a

50 Staatsarchiv Oldenburg, Bestand I40-5, Nr. I I93: Verfahren Hartmann, 5 Js I I07/47, 9 Ks 2/50, vol. I, pp. 36-37: testimony (under oath) of Mia Cornelßen, geb. Krumnow, Wilhelmshaven, 22 Nov. I946. See also vol. I, pp. I91-206: StA Oldenburg, Anklage Hartmann, s Js I 107/47, I3 Apr. I949 (reference on pp. 20I-2).

5I Ibid., vol. I, pp. I9I-206: StA Oldenburg, Anklage Hartmann, s Js I I07/47, I 3 Apr. 1949 (reference on p. 204).

52 Ibid., vol. I, p. I7: interrogation of Anna Magarethe Wille, Jever, 7 May I948.

53 Ibid., vol. I, pp. I9 I-206: StA Oldenburg, Anklage Hartmann, s Js I I07/47, I 3 Apr. 1949 (both references on p. 205).

54 Ibid., vol. 2, pp. I34-69: LG Oldenburg, Urteil Hartmann, 9 Ks 2/50, Is Feb. I950 (references on pp. I6669). I discussed Mia Cornelßen's story with a colleagues wife, Dr. Kay Kohler, who happens to be an OBGYN. I asked her whether Mia's account was credible. Dr. Kohler thought that it was plausible. Of course, she did not examine the patient and had to rely on second hand information. But so did the expert Dr. Jacobs. 
decision that reflected the vote, because, unlike our legal system, the German law does not permit a dissent from the bench. Of course, this is just a supposition.

One other point. Aware of the accusation against Wille that he had also mistreated Jewish women prisoners, the court stated: »Auch die einige Tage vorher anläßlich der Judenverfolgung in das Polizeigefängnis eingelieferten jüdischen Häftlinge hat er, wie der Zeuge Lewy glaubwürdig bekundet hat, sehr menschlich und hilfsbereit behandelt. «s We can assume that the witness Lewy was Jewish (although not a woman). But of course we know that in those days every German Nazi carried a Persilschein in his pocket. And I have found, even in Jewish Kristallnacht cases, a number of letters of support written from New York by Jewish refugees to support some Kristallnacht perpetrator.

The case against the perpetrators responsible for the physical attack against the Cornelßens' property proved less controversial. Basically, there was proof that the party had planned and implemented the attack. There was agreement that both SA and HJ were ordered to report in civilian clothes for a special meeting, and that they were directed to assembly points near the home of the Cornelßens, where the $\mathrm{HJ}$ was asked to collect stones. There was no doubt that the assembled crowd threw stones to break all windows, that they broke into the Cornelßens' apartment and demolished its furniture. But who did all this - could not be established.

While there was agreement about the events, the large number of onlookers could not name the participants. Most Sande citizens, who obviously knew most of the other village inhabitants, told investigators that they could not tell who had stood next to them in the crowd, because it had been too dark to recognize anyone. Few were as honest as the Cornelßens neighbor Peters; she supported the Cornelßens and was highly regarded by the police even when she did not provide them with answers: »Die Zeugin Peters ist eine ruhige anscheinend zuverlässige Frau, die keinem zu Nahe treten möchte. Sie war bei der Vernehmung ängstlich bemüht, keine Namen zu nennen, obwohl oder gerade weil sie die meisten Beteiligten sehr gut kennt. « ${ }^{56}$ The actual perpetrators of violence could also identify no one. But they offered an explanation. They argued that the vandalism had been the work of I $3^{-}$I 4 year-old boys, motivated by their quarrel with Mia Cornelßen over the »Berliner Pflanze« song. In other words, everything had just been a foolish escapade of young boys, in other words a Dummerjungenstreich. ${ }^{57}$

Eventually, the state's attorney indicted nine SA men; eight of them because they had been recognizably present in the crowd, including the men Gösseljohanns had asked, on Hartmann's recommendation, to guard the building. The state's attorney could not prove that they had actually participated in the violence; Hartmann claimed that he had picked them, because they were »zufällig anwesend. $\aleph^{8}$ But this also made them guilty under $\$ I 25 StGB: Landfriedensbruch. The law covers members of a Zusammenrottung even if they do not commit violence, because by their presence they provide support and encouragement to those who do commit violence. 59 In addition, the state's attorney requested that alongside the German law the crime against humanity should be charged under Control Council Law No. Io, something the court rejected. ${ }^{60}$ In the end the court did not convict the eight SA-men.

5s Ibid., vol. 2, pp. I 34-69: LG Oldenburg, Urteil Hartmann, 9 Ks 2/50, Is Feb. I950 (references on p. I68).

56 Ibid., vol I, pp. 39-40: Interrogation of Antje Peters, verwitwete Metzdorf, geb. Kampen, Wilhelmshaven, 25 Nov. 1946 (note by Kripo officer).

57 Ibid., vol. I, pp. 77-79: interrogation of Hermann Johann Hartmann, Is Apr. 1947.

58 Ibid., vol. I, pp. I9I-206: StA Oldenburg, Anklage Hartmann, 5 Js I I07/47, I 3 Apr. I 949 (reference on p. I99); vol. I, pp. 77-79: interrogation of Hermann Johann Hartmann, Is Apr. 1947.

59 See Ibid., vol. 2, pp. I 34-69: LG Oldenburg, Urteil Hartmann, 9 Ks 2/50, I 5 Feb. I 950 (reference on p. I 50 ).

60 Ibid., vol. 2, pp. I 34-69: LG Oldenburg, Urteil Hartmann, 9 Ks 2/50, Is Feb. I950 (reference on p. I6I). 
Only one person - Hermann Hartmann - would actually be convicted. The evidence was overwhelming that this Sande teacher and SA Sturmführer had been the instigator and ringleader of the attack upon the Cornelßens. But he received a sentence of only ten months. The indictment had pointed out, correctly in my opinion, that »Die eben erst gegen die jüdische Bevölkerung durchgeführte Aktion war daher der gegebene Anlass, nunmehr in ähnlicher Weise offen gegen die Eheleute Cornelßen vorzugehen. ${ }^{61}$ The court used this to argue that in both the anti-Jewish operation and the nonJewish related events in Sande, the true instigators were »höhere Dienststellen «, thus granting Hartmann mitigating circumstances in regard to the severity of the sentence. $^{62}$

Hartmann appealed his conviction and sentence to the Bundesgerichtshof, which ruled against him on 2 I March I952.63 Thus Case No. I I 93 ended - four years after its inception; twelve years after the crime had been committed.

Oldenburg Case No. I 193 is not just interesting, but may also tell us something new about the Kristallnacht events. So in conclusion, I will point to four aspects that may, in a minor way, lead us to see Kristallnacht in a larger context.

(I) Kristallnacht was a departure from the German government's stance as a law-andorder regime. Not only did the Nazi leadership organize violence, but it also encouraged popular participation. The conventional opinion that the German »street « (a term our current media likes to use) did not approve of the violence should be revised. In Case No. I 93 we have seen that the violence became a public spectacle with mass participation of the population. And by the way, this is also observable, more than expected, in Kristallnacht cases involving Jews. Furthermore, this case shows how violence, once unleashed, could not always be contained. The postwar judiciary, both the state's attorney and the court, believed that the Kristallnacht events in Sande persuaded the perpetrators that the same methods could be applied against the Cornelßens.

(2) Case No. I 93 shows that not only the antisemitic ideology of national socialism motivated the population, although the regime's functionaries used it, but that also a great deal of plain xenophobia was involved. In the small towns and villages hostility against outsiders was strong; we thus see that Kristallnacht in general was more violent in the countryside and small towns than in more cosmopolitan large cities (Vienna was an exception; but I get the impression that there the additudes in the individual Bezirke were similar to those in a village). The Cornelßens, especially the wife, were outsiders; as the postwar court described it, they were seen as standing apart from the Volksgemeinschaft.

(3) In this particular case few onlookers talked, no one identified perpetrators, and no one showed remorse. This differed from many cases involving Jews, cases in which most witnesses named perpetrators and most professed regret. How do we explain the difference? It could of course have been due to the changed power relationships of Allied occupation, which resulted in a taboo concerning Jews (one that has slowly eroded). I believe, however, that it is more likely because the Jews had disappeared and, suddenly, dead Jews became popular. In Case No. I i93, however, the Cornelßens came back, only to discover that the town's dislike of them had survived the demise of the regime.

6r Ibid., vol. I, pp. I9I-206: StA Oldenburg, Anklage Hartmann, 5 Js I Io7/47, I 3 Apr. I949 (reference on p. 200).

62 Ibid., vol. 2, pp. I34-69: LG Oldenburg, Urteil Hartmann, 9 Ks 2/50, Is Feb. I950 (reference on p. I62).

63 Ibid., vol. 2, pp. 227-29: Bundesgerichtshof, Revisionsurteil Hermann Hartmann, 2 I Mar. I952. 
(4) Considering the greater hostility directed against Mia Cornelßen, I cannot escape the feeling that gender had something to do with the events in Sande. The attitudes of both the men and the women of Sande are reminiscent of the witch trials of an earlier age, a relationship Norman Cohn discussed in »The Pursuit of the Millennium «. ${ }^{64}$ In general, the prevalence of incarceration of Jewish women during Kristallnacht has until now been underestimated.

The defeat and occupation of Germany in 1945 is usually described as the Zero Hour. In Case No. I I 93, the new beginning after point zero is represented by Gösseljohanns' suspension for less than a year and by the incarceration of Hartmann for no more than ten months. Everything else in the case - the attitude of the police investigators, the opinion of the physicians, the stone-walling of the citizens of Sande, and the vote of the jurors - shows that there was a hell of a lot of continuity. 